\title{
Acute Respiratory Effects on Workers Exposed to Metalworking Fluid Aerosols in an Automotive Transmission Plant
}

\author{
Thomas Robins, MD, MPH, ${ }^{1 *}$ Noah Seixas, PhD, MPH, ${ }^{2}$ Alfred Franzblau, MD, ${ }^{1}$ Lori Abrams, PhD, ${ }^{1}$ \\ Susan Minick, MS, ${ }^{1}$ Harriet Burge, PhD, ${ }^{3}$ and $M$. Anthony Schork, PhD $^{1}$
}

\begin{abstract}
Exposure to metalworking fluids has been linked to modest cross-shift reductions in FEV $V_{1}$ and occupational asthma. To identify responsible agents, we measured personal exposures to thoracic particulate (TP), viable plus nonviable thoracic bacteria (BAC), and vapor phase nicotine (VPN) (as a surrogate for tobacco particulate) among 83 machinists exposed to soluble oils and 46 dry assemblers working in an automotive transmission machining plant using biocides infrequently. The participants completed interviews and performed pre- and postshift spirometry on Monday and Thursday of the same week in each of three rounds of data collection (June 1992, January 1993, June 1993). Generalized estimating equations were used to combine information across rounds in multiple regression models of cross-shift and cross-week changes in forced expiratory volume, 1 second $\left(F E V_{I}\right)$ and forced vital capacity (FVC). Mean seniority was 19 years among machinists. Mean personal TP levels were $0.41 \mathrm{mg} / \mathrm{m}^{3}$ in machinists and $0.13 \mathrm{mg} / \mathrm{m}^{3}$ in assemblers. Six of the 83 machinists and none of the 46 assemblers experienced a greater than $19 \%$ cross-shift decrement in $F E V_{1}$ or FVC at least once $(p=.07)$. In regression models using either TP or BAC, among subjects with lower baseline (Monday preshift) $F E V_{I} / F V C$ ratios, increasing exposure was significantly associated with increasing cross-shift decrements in FEV $V_{I}$ and FVC in linear models, and with increased likelihood of a $10 \%$ or greater cross-shift decrement in FEV $V_{1}$ or FVC in logistic models. Adjustment of TP for VPN did not affect models significantly. We conclude that clinically important cross-shift decrements in pulmonary function are associated with exposure to metalworking fluid aerosols within a high-seniority population. Am. J. Ind. Med. 31:510-524, 1997. 인 1997 Wiley-Liss, Inc.
\end{abstract}

KEY WORDS: occupational asthma; pulmonary function; endotoxin; diurnal variations; metalworking fluids; automotive workers

\section{INTRODUCTION}

Metal machining requires lubrication and dispersion of generated heat. Several distinct classes of metalworking

${ }^{1}$ Department of Environmental and Industrial Health, University of Michigan. ${ }^{2}$ Department of Environmental Health, University of Washington.

${ }^{3}$ Department of Environmental Health, Harvard University.

Contract Grant sponsor: United Automobile Workers/General Motors National $J$ oint Committee of Health and Safety.

*Correspondence to: Dr. T. Robins, School of Public Health, 1420 Washington Heights, Ann Arbor, MI 48109-2029.

Accepted for publication 12 September 1996 fluids, ("metalworking fluids," 'cutting fluids," 'coolants'), have evolved to accomplish these goals. Straight oils contain mineral oil, but no water. Emulsified (soluble) oils are composed of a few percent mineral oil suspended in water. Because of the presence of mineral oil they retain some of the lubrication advantages of straight oils but also have excellent cooling capacity due to water. Emulsified oils usually contain a variety of additional materials, including emulsifiers, biocides, extreme-pressure agents, antifoaming agents, corrosion inhibitors, caustics to maintain high $\mathrm{pH}$, colorants, and odorants. Synthetic oils do not depend on mineral oil to achieve lubrication; rather they contain synthetic chemicals such as polyglycols and/or ethanol- 
amines, plus many of the additives listed above for emulsified oils. In addition to the materials that are purposefully introduced into metalworking fluids, numerous contaminants are known to appear with use, such as bacteria, fungi, and the metabolic products of viable organisms, trace metal contaminants from the metalworking process, and 'tramp oil' (lubrication oil that has leaked from machines performing metal working-processes).

The National Occupation Exposure Survey conducted by NIOSH in 1981-1983 estimated that 1.2 million workers in the United States were occupationally exposed to metalworking fluids [NIOSH, 1977]. Several previous studies have reported that metalworking fluids, or their individual components, can cause impairment of airway function [Hendy et al., 1985; Kennedy et al., 1989; Robertson et al., 1988]. However, the mechanisms, magnitude, and the specific agent(s) responsible for airway dysfunction among workers exposed to different metalworking fluids are incompletely characterized.

Our study was specifically designed to address the acute effect of exposure to metalworking fluids on respiratory health. Cross-shift and cross-week changes in pulmonary function and respiratory symptoms were the primary outcome measures. Although these acute effects are not necessarily disabling, they may cause significant discomfort that results in temporary disability (for example, wheezing or shortness of breath). In addition, acute pulmonary function decline may be indicative of occupational asthma or lead to progressively more serious impairment and disability [Peters, 1974; Weill, 1984; Becklake et al.; 1988; Hankinson and Hodous, 1983; Christiani et al.; 1994; Glindmeyer, 1994; Becklake, 1995].

\section{METHODS}

\section{Subject Selection}

This study was conducted at an automotive transmission plant in the Midwest. The plant has two major machining departments, the Case and the Valve Body Departments. Both use soluble oils supplied from one of three large sumps. Use of biocides in metalworking fluids was infrequent and restricted entirely to one of the two systems serving the grinding operations in Valve Body. Use of this fluid was discontinued after the first round of the study. Final Assembly, chosen as the department from which to draw comparison subjects, was physically isolated from, and under positive air pressure with respect to, machining areas and contained no identifiable respiratory hazards.

The study was introduced to the eligible plant population through a series of mass meetings. Subsequently, all persons working in Case and in Valve Body believed to have experienced metalworking fluid exposure were individually recruited by University of Michigan study personnel, as was a stratified random sample of workers in Final Assembly with age and race distributions similar to those of the subjects working in machining areas.

This study involved a preliminary exposure evaluation (April 1992) and three rounds of full data collection: June 1992, January 1993, and June 1993. Three rounds of study were chosen to increase the power of the study, given the limited number of exposed and unexposed subjects, and to examine seasonal (summer vs. winter) effects. During each round of the study, participants completed questionnaires and underwent pulmonary function testing (spirometry) on the first work day of the week (Monday) before and after shift and on the fourth work day of the same week (Thursday) before and after shift, and they wore air-sampling devices on these days. Monday was chosen because any exposure-related effects might be expected to be more pronounced after two days away from work; Thursday so that changes occurring over a work week could be examined (Friday was excluded because of high absenteeism on this day of the week).

\section{Exposure Measures}

Exposure assessment procedures are described in detail elsewhere [Abrams et al., submitted]. Air samples were collected with constant-flow sampling pumps calibrated to 2 liters/minute. All thoracic samples (particulate, bacteria, and personal endotoxin) were obtained with a PEM sampling device (Personal Environmental Monitor, manufactured by MSP Corp., Minneapolis, MN) equipped with a Nuclepore polycarbonate membrane filter (Costar Corporation, Cambridge, MA; 37-mm diameter, $0.8-\mu \mathrm{m}$ pore size). The PEM is a two-stage sampler consisting of a single impaction stage (preselector) and a backup filter. The preselector has an upper median cut diameter of $10 \mu \mathrm{m}$, resulting in collection of approximately the "thoracic" fraction particulate on the filter [Marple, 1989]. All air samples represented at least 5 $1 / 2$ hours of sampling.

In each of the three rounds, all study participants who worked in metalworking fluid areas wore a thoracic fraction sampler. During Round 2, all study participants working in assembly also wore a thoracic fraction sampler. In Rounds 1 and 3, a random sample of assemblers (18 of 34 in Round 1; 15 of 22 in Rounds 3) wore a thoracic fraction sampler. All filters were analyzed for thoracic particulate; a randomly selected subset of filters also were analyzed for thoracic bacteria (viable plus nonviable). Filters and PEMs used for bacterial analyses were handled so as to minimize contamination. After sampling, filters were removed from PEMs, placed in clean empty cassettes, and treated with propylene oxide vapor to halt possible bacterial growth. Bacteria were quantified by washing the collected particulate off the sample filter with $0.02 \%$ Tween 20 in distilled water. Tween suspensions were preserved with $1 \%$ formaldehyde and 
stored at $5{ }^{\circ} \mathrm{C}$ (in Round 3, preserved samples were mailed overnight to Boston because the responsible investigator had relocated her laboratory). At a later date, a portion of the resulting suspension was refiltered through a black-stained polycarbonate filter (26-mm diameter, $0.2-\mu \mathrm{m}$ pore size; Costar Corp., Cambridge, MA). This filter was then stained with $0.1 \%$ acridine orange (AO) in distilled water and mounted in immersion oil on a microscope slide. Bacteria were counted manually under a florescence microscope [Hobbie et al., 1977].

A mathematical model for predicting levels of bacteria in air from other measures of exposure was developed and validated with data derived from the current study. Methods and results of bacteria exposure modeling will be discussed in a separate article. The exposure response models presented here that used bacteria as the exposure parameter are based on a combination of measured and modeled values for personal exposure to bacteria.

Personal exposures to thoracic particulate and thoracic bacteria were selected as the key exposure indices. Because measures of personal exposures to endotoxin were available only in Round 3, these were not used in most analyses [Milton, Gere, et al., 1990]. In addition, vapor phase nicotine (VPN) was measured in order to adjust total thoracic particulate for the contribution of particulate derived from tobacco smoke [Hammond et al., 1987; Leaderer and Hammond, 1991]. The findings using tobacco-adjusted thoracic particulate were essentially identical to those using total thoracic particulate and are not presented here.

\section{Questionnaires}

A brief questionnaire was administered to each participant prior to completion of each spirometry test. These questionnaires were designed primarily to capture information pertaining to acute symptoms, recent respiratory infections, current medications used for respiratory illness, cigarette smoking within the past hour, and daily work practices. In addition, a more in-depth background questionnaire was administered to each subject during Round 1 of the study. The background questionnaire included a modified version of the American Thoracic Society Adult Respiratory Questionnaire [American Thoracic Society, 1978] with additional questions regarding asthma and atopic history as well as standard questions on medical history, respiratory symptoms, and lifetime smoking history. There were also questions pertaining to current and past employment, and possible exposures to respiratory irritants in previous jobs.

Cough was defined as a yes response on the in-depth questionnaire to any of the following three questions: (1) 'Do you usually have a cough?'; (2) 'Do you usually cough at all on getting up, or first thing in the morning?'; and (3) 'Do you usually cough at all during the rest of the day or night?" Chronic cough was defined as having a cough, responding yes to the question 'Do you usually cough like this on most days for 3 consecutive months or more during the year?' and having had this cough for at least two years. Phlegm and chronic phlegm were defined analogously to cough and chronic cough. Chronic bronchitis was defined as having both chronic cough and chronic phlegm. Wheezing was defined as a yes response to either of the two following questions: (1) 'Does your chest occasionally sound wheezy or whistling apart from colds?' and (2) 'Does your chest sound wheezy or whistling most days or nights?' Wheezing with dyspnea was defined by a yes response to the question 'Have you ever had an attack of wheezing that has made you feel short of breath?' Grade 1 dyspnea was defined by a yes response to the question "Are you troubled by shortness of breath when hurrying on the level or walking up a slight hill?" Grade 2 dyspnea was defined by a yes response to the previous question and to the question 'Do you have to walk slower than people of your age on the level because of breathlessness?" Asthma was defined as a yes response to the question 'Have you ever had asthma?' Asthma prior to employment at the facility under study was defined as a yes response to the previous question and to the question 'Did you have asthma before you worked at this facility?"

\section{Pulmonary Function Testing}

Spirometry testing was performed following all current ATS recommendations [American Thoracic Society, 1987] with computerized water-sealed volume-displacement instruments (Warren E. Collins Eagle II with Survey; Warren E. Collins, Inc., Braintree, MA) calibrated three times daily with a 3-liter syringe. Adjustments for temperature and barometric pressure were made according to the manufacturer's recommendation. Trained technicians attempted to obtain a minimum of three acceptable maneuvers of at least a 6-second duration for which the two best forced vital capacity $(\mathrm{FVC})$ and forced expiratory volume $\left(\mathrm{FEV}_{1}\right)$ figures were within $5 \%$ of each other. Prediction formulas for $\mathrm{FEV}_{1}$ and FVC were derived from general population data from six U.S. cities, including the recommended correction factor for blacks [Dockery et al., 1985].

\section{Statistical Methods}

Percentage change in FVC and $\mathrm{FEV}_{1}$ were calculated for Monday cross-shift, Thursday cross-shift, and crossweek as follows: percentage change $=100 \times$ (final reading initial reading)/initial reading, so that a negative value represents a fall in the $\mathrm{FEV}_{1}$ or FVC over the workshift or week. For the cross-week change, Thursday postshift was used as the final reading and Monday preshift the initial reading.

Approximate 25 and 75 percentiles of the thoracic particulate concentration from Round 1 were used to group all workers (machinists and assemblers) into low $(<0.157$ 
$\left.\mathrm{mg} / \mathrm{m}^{3}\right)$, medium $\left(0.157-0.468 \mathrm{mg} / \mathrm{m}^{3}\right)$, and high $(>0.468$ $\mathrm{mg} / \mathrm{m}^{3}$ ) exposure categories. The same absolute numeric cutoffs were used in Rounds 2 and 3. For comparability to the method of analyses of Kennedy et al. [1989], the percentages of workers with at least a 5\% decrease in FVC or $\mathrm{FEV}_{1}$ in each exposure category were calculated.

Associations between thoracic particulate concentration or bacteria concentration and change in $\mathrm{FVC}$ and $\mathrm{FEV}_{1}$ across the workshift were investigated with multivariable linear and logistic models. Linear and logistic models that combined Monday and Thursday data from all rounds were fit by the generalized estimating equation (GEE) method to account for lack of independence of observations on the same individual [Liang and Zeger, 1986; Zeger and Liang, 1986]. Monday and Thursday data were combined to increase power and because in no case was an indicator variable for day of week significant at a $p=.10$ level. In initial logistic analyses, models using a $5 \%$ or greater decrement in $\mathrm{FEV}_{1}$ or FVC as the outcome variable were compared with those using a $10 \%$ or greater decrement. The $10 \%$ or greater decrement models were selected for further analyses and are presented here because: (a) the 10\% decrements are considered to be of greater clinical relevance than 5\% decrements, and (b) the 10\% models generally had smaller model mean square errors. Because subjects reporting current asthma $(N=8)$ tended to have much greater variability in scatter plots of cross-shift change in $\mathrm{FEV}_{1}$ and FVC, models including and excluding these subjects were compared. Because exclusion of those with current asthma had little effect on parameter estimates or their significance, these models are not presented here. In general, failure to meet 5\% criteria for reproducibility of $\mathrm{FEV}_{1}$ and $\mathrm{FVC}$ was not a criterion for exclusion. However, two subjects with very poor reliability in their pulmonary function tests, as judged by extreme lack of reproducibility and the shapes of volume-time curves, were deleted. A decision was reached early in the analyses to include a measure of baseline obstruction (i.e., Monday preshift $\mathrm{FEV}_{1} / \mathrm{FVC}$ ratio) as well as a baseline obstruction/exposure measure interaction term in all final models, because these terms were frequently highly significant in preliminary models.

The natural logs of thoracic particulate and thoracic bacteria were used in models, rather than simple thoracic particulate, on the basis of findings from prior animal and human studies [Schaper and Detwiler, 1991; Castellan et al., 1987] that decrements in pulmonary function were linearly related to $\log$ transformed measures of particulate or endotoxin, a bacterial product. Initial candidate variables for entry into regression models included exposure (natural log of thoracic particulate or natural $\log$ of thoracic bacteria), shift ( $1 \mathrm{st}=6$ am to $2 \mathrm{pm}, 2 \mathrm{nd}=3 \mathrm{pm}$ to $11 \mathrm{pm}$ ), baseline obstruction, exposure $\times$ baseline obstruction, department (machining area vs. assembly), smoking status (current vs. ex or never), and pack-years smoked. Age was not included because of its high correlation with pack-years smoked and obstruction. Initial models were difficult to interpret owing to multicollinearity between, on the one hand, baseline obstruction, smoking status, and pack-years, and, on the other hand, exposure and department. In addition, a generally consistent pattern of greater significance of baseline obstruction terms as compared with smoking-related terms was observed. For these reasons smoking status, pack-years, and department were dropped from final models presented here.

\section{RESULTS}

\section{Participation}

In Round 1, a total of 220 eligible employees were asked if they would be willing to participate in the study, of whom 185 agreed to participate; 35 refused. The agreement rate was $82 \%$ among assemblers and $85 \%$ among machinists. Among these 185 , there were 148 employees who were then scheduled to participate in the study: 120 who did participate, 14 who refused on the day of the study, 1 who was absent from the plant owing to sickness, and 13 who were absent from the plant for vacation or unknown reasons. There were no significant differences in age, seniority, race, or shift between participating and nonparticipating assemblers. Among machinists, participants were more likely than nonparticipants to be black (49\% vs. $17 \%)$ and to be on second shift $(55 \%$ vs. $31 \%$ ), but there were no significant differences in age or seniority.

In Round 2, a total of 119 eligible employee were asked to participate in the study, of which 109 agreed and 10 refused. These 119 included all Round 1 participants still working in appropriate jobs plus some new recruits from Assembly. All 109 employees who agreed to participate were scheduled. Of those scheduled, 90 participated, 14 refused on the day of the study, 2 were absent from the plant owing to sickness, and 3 were absent from the plant for vacation or unknown reasons. In this round, there were no significant differences in age, seniority, race, or shift between participating and nonparticipating assemblers or between participating and nonparticipating machinists.

In Round 3, a total of 91 eligible employees were asked to participate, of which 83 agreed and 8 refused. These 91 included all Round 1 and Round 2 participants still working in appropriate jobs. All 83 of those who agreed were scheduled. Of those scheduled, 57 participated, 13 refused on the day of the study, 3 were absent from the plant owing to sickness, and 10 were absent from the plant for vacation or unknown reasons. No significant differences were found between participating and nonparticipating machinists with respect to mean age, mean seniority, race, or shift. For assemblers, participants were significantly 
TABLE I. Demographics of Participants in Study of Metalworking Fluid Exposure Effects

\begin{tabular}{|c|c|c|c|c|c|c|}
\hline & \multicolumn{2}{|c|}{ Round 1} & \multicolumn{2}{|c|}{ Round 2} & \multicolumn{2}{|c|}{ Round 3} \\
\hline & Assemblers & Machinists & Assemblers & Machinists & Assemblers & Machinists \\
\hline No. & 34 & 83 & $34^{a}$ & 52 & 22 & 35 \\
\hline Mean age, yr & $40.3 \pm 1.2$ & $45.3 \pm 1.0^{b}$ & $41.3 \pm 0.9$ & $47.6 \pm 1.1^{c}$ & $41.6 \pm 1.4$ & $46.8 \pm 1.4^{b}$ \\
\hline Mean seniority, yr & $12.1 \pm 0.9$ & $18.6 \pm 0.8^{c}$ & $13.5 \pm 1.0$ & $19.9 \pm 0.9 c$ & $13.4 \pm 1.1$ & $19.4 \pm 1.1^{c}$ \\
\hline Mean height, inches & $69.0 \pm 0.5$ & $69.6 \pm 0.3$ & $69.8 \pm 0.5$ & $69.3 \pm 0.4$ & $70.3 \pm 0.5$ & $69.6 \pm 0.6$ \\
\hline Race, \% black & 35.3 & 50.6 & 35.3 & 42.3 & 27.3 & 48.6 \\
\hline Shift, \% 1st shift & 70.6 & $44.6^{b}$ & 64.7 & 55.8 & 77.3 & 54.3 \\
\hline \multicolumn{7}{|l|}{ Smoking status: } \\
\hline Never smokers, \% & 26.5 & 19.3 & 29.4 & 11.5 & 36.4 & 20.0 \\
\hline Ex-smokers, \% & 38.2 & 43.4 & 35.3 & 48.1 & 45.4 & 34.3 \\
\hline Current smokers, $\%$ & 35.3 & 37.4 & 35.3 & 40.4 & 18.2 & 45.7 \\
\hline History of asthma predating auto employment, $\%$ & 8.8 & 4.8 & 8.8 & 7.7 & 9.1 & 8.6 \\
\hline
\end{tabular}

alncludes 22 assemblers who also participated in Round 1 plus 12 additional assemblers recruited in Round 2 .

bDiffers significantly from assemblers $(.01<p<.05)$.

'Differs significantly from assemblers $(p<.001)$.

younger (42 vs. 45 years) and were more likely to be on first shift $(6 \mathrm{am}-2 \mathrm{pm})(77 \%$ vs. $37 \%)$ than nonparticipants.

Demographic characteristics for Round 1 participants (Table I) show that there were significant differences in age, seniority, and shift between assemblers and machinists: Machinists tended to be older, had more seniority, and were more likely to be on the second shift. There were no significant differences with respect to height, race, smoking status, or history of asthma. In Rounds 2 and 3, machinists were again significantly older and had more seniority but differences in shift worked were no longer significant. Though never reaching statistical significance, in each round machinists were more likely to be black and less likely never to have been smokers.

Compared with the 76 subjects who participated in both Round 1 and Round 2, the 44 subjects who participated in Round 1 but not Round 2 were significantly younger, had less seniority, and were more likely to be black and to be on second shift (not shown). These differences were due mainly to significant differences between machinists who participated in both rounds compared with those who were lost to follow-up. There were no significant differences between people who participated both in Round 2 and Round 3 and those lost to follow-up in Round 3 with respect to age, seniority, height, race, shift, smoking status, or history of asthma, even when assemblers and machinists were considered separately (not shown).

\section{Exposure Results}

The mean concentration of thoracic particulate over the three rounds of the study were $0.13 \mathrm{mg} / \mathrm{m}^{3}$ in Assembly, 0.32 $\mathrm{mg} / \mathrm{m}^{3}$ in Valve body, and $0.56 \mathrm{mg} / \mathrm{m}^{3}$ in Case. Average personal exposures to thoracic bacteria were 0.38 bacteria/cc in Assembly, 0.87 bacteria/cc in Valve Body, and 2.66 bacteria/cc in Case. Average personal endotoxin levels, which were collected only in Round 3, were 16.4 endotoxin units $/ \mathrm{m}^{3}$ in Assembly, $34.7 \mathrm{EU} / \mathrm{m}^{3}$ in Valve Body, and 234 $\mathrm{EU} / \mathrm{m}^{3}$ in Case. More detailed exposure results are presented elsewhere [Abrams et al., submitted for publication].

\section{Baseline Lung Function}

In Round 1, baseline (i.e., Monday before shift) percentage predicted for $\mathrm{FVC}$ and $\mathrm{FEV}_{1}$ in the study population were, on average, higher than predicted for the general nonsmoking population (112\% predicted and $109 \%$ predicted, respectively). There were no significant differences in baseline PFTs by department or shift. Current smokers had a significantly lower mean $\mathrm{FEV}_{1}$ percentage predicted (104) than ex-smokers or never smokers (112 and 115, respectively). Similar relationships were seen in the percentage predicted values for Round 2 and Round 3. Comparing across rounds, paired $t$ tests demonstrated that mean percentage predicted values for Round 1 and Round 3 were significantly higher than those in Round 2. Mean paired differences for $\mathrm{FVC}$ and $\mathrm{FEV}_{1}$ percentage predicted were, respectively, $2.1 \%$ and $4.9 \%$ for Round 1 versus Round 2, and $4.2 \%$ and $2.6 \%$ for Round 3 versus Round 2.

\section{Cross-Shift and Cross-Week Changes in Lung Function}

In each of the three rounds, machinists generally appeared more likely than assemblers to experience cross- 
Round $1(\mathbf{n = 1 2 0})$

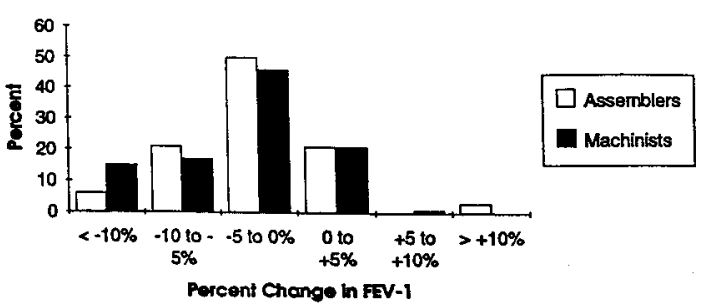

Round $2(n=90)$

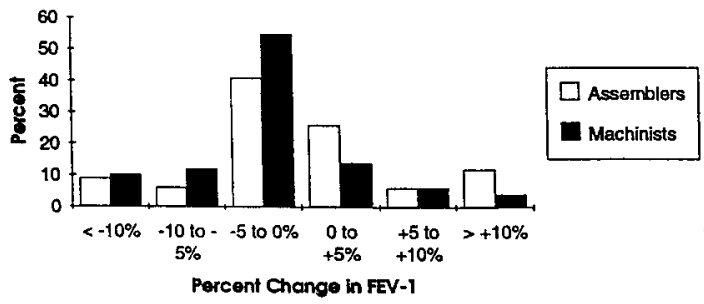

Round 3 ( $n=55$ )

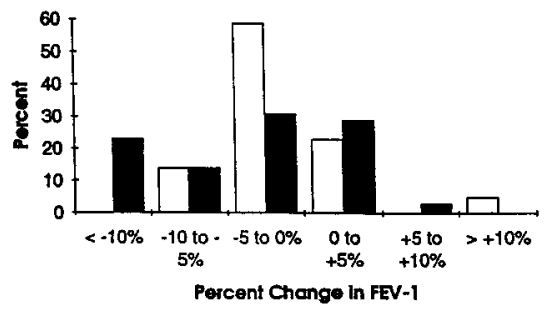

FIGURE 1. Distribution of cross-shift change in $\mathrm{FEV}_{1}$ on Monday for assemblers and machinists.

shift decrements in PFTs of 5\% or greater. As an example, comparative distributions for Monday $\mathrm{FEV}_{1}$ are shown in Figure 1. The percentage of machinists versus assemblers, respectively, experiencing Monday cross-shift decrements of $5 \%$ or greater in at least one round were the following: for $\mathrm{FEV}_{1}, 42.9 \%$ versus $26.8 \%$; for FVC, $41.6 \%$ versus $19.5 \%$. Analogous results for Monday cross-shift decrements of $10 \%$ or greater were $16.9 \%$ versus $7.3 \%$ for $\mathrm{FEV}_{1} ; 6.5 \%$ versus $2.4 \%$ for FVC. As compared with Monday's results, those for Thursday showed a similar pattern for FVC, but little difference between machinists and assemblers for $\mathrm{FEV}_{1}$.

As described in Methods, subjects were grouped into three exposures categories defined by approximately the 25 th and 75 th percentiles of thoracic particulate measures, and the percentages of workers having at least a $5 \%$ cross-shift decrement in FVC or $\mathrm{FEV}_{1}$ in each exposure group were calculated. For Round 1 on Monday, there was strong evidence $(p<.0005)$ for a linear trend in response for $\mathrm{FVC}$ but not for $\mathrm{FEV}_{1}$, although the response percentage for $\mathrm{FEV}_{1}$ did increase as exposure increased (Fig. 2). In Round 2, a qualitatively similar relationship was seen for Monday FVC, although the trend was not significant. Although there was no evidence for a linear trend in $\mathrm{FEV}_{\mathrm{l}}$, there was a marginally significant difference in percentage response between the high-exposure group and the low- and mediumexposure groups combined ( $p=.062$ ). For Round 3 on Monday, percentages of subjects with $5 \%$ decrements in FVC or $\mathrm{FEV}_{1}$ increase as exposure increases, but the trends are not statistically significant. For Round 1 on Thursday (not shown), there was marginal evidence for a linear trend in response for both $\mathrm{FVC}(p=.053)$ and $\mathrm{FEV}_{1}(p=.061)$ For Round 2 on Thursday there was marginal evidence for a linear trend for FVC, but no evidence for an association between exposure group and $\mathrm{FEV}_{1}$ response. For Round 3 on Thursday, no one in the high-exposure group had a $5 \%$ decrement in either FVC or $\mathrm{FEV}_{1}$. In summary, a consistent dose-related pattern of greater percentages of subjects with $5 \%$ decrements in $\mathrm{FEV}_{1}$ and $\mathrm{FVC}$ were seen across all rounds on Monday. The pattern for Thursday did not show such consistency.

Table II shows the frequency of $10 \%$ or greater crossshift decrements in $\mathrm{FEV}_{1}$ or FVC stratified by current
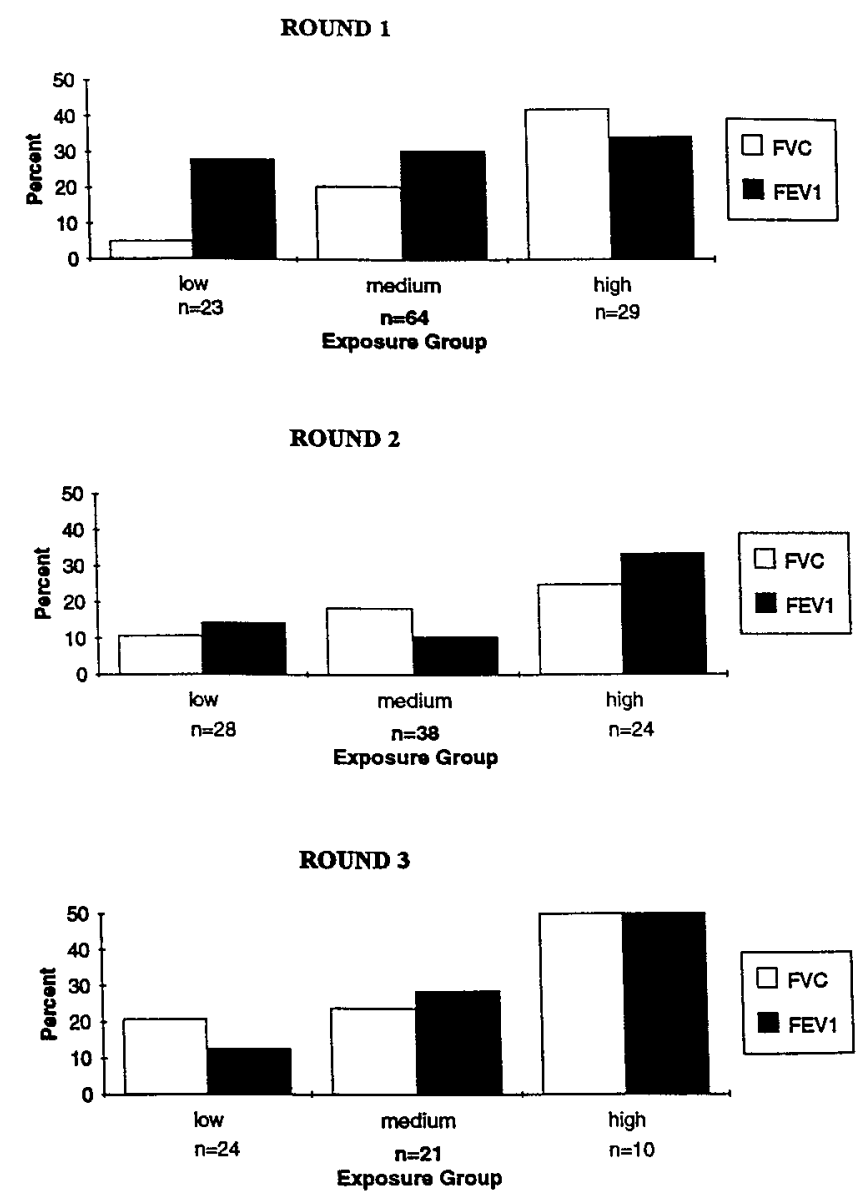

FIGURE 2. Percentage of subjects (all departments) with at least a $5 \%$ cross-shift decrement on Monday in FVC and $\mathrm{FEV}_{1}$ by exposure group. See text for definitions of exposure groups. 
TABLE II. Percentage of Observations with Subject Experiencing a $10 \%$ or Greater Cross-Shift Decrement in Pulmonary Function Test

\begin{tabular}{lccr} 
& $\begin{array}{c}\text { Number of } \\
\text { observations }\end{array}$ & $\begin{array}{c}\text { \% with } \\
\text { decrement } \\
\text { in FEV }\end{array}$ & $\begin{array}{c}\text { \% with } \\
\text { decrement } \\
\text { in FVC }\end{array}$ \\
\hline Nonobstructed nonsmoker & 241 & $2.9(7)^{\mathrm{a}}$ & $1.2(3)$ \\
Nonobstructed current smoker & 102 & $8.8(9)$ & $3.9(4)$ \\
Obstructed $^{b}$ nonsmoker & 25 & $8.0(2)$ & $8.0(2)$ \\
Obstructedb $^{b}$ current smoker & 59 & $25.4(15)$ & $15.3(9)$ \\
\hline
\end{tabular}

aNumbers in parentheses denote number of observations.

bobstructed $=$ Monday preshift FEV $1 / F V C$ ratio $\leq 0.72$.

smoking status and presence of (baseline) obstruction defined as Monday preshift $\mathrm{FEV}_{1} / \mathrm{FVC}$ ratio of 0.72 or less. Current smokers are substantially more likely to be obstructed than other subjects: 59 of 161 observations (36.6\%) versus 25 of 266 observations (9.4\%). The presence of either current smoking or baseline obstruction appears to increase the likelihood of a $10 \%$ or greater decrement in pulmonary function, although the data on obstructed nonsmokers should be interpreted with caution because of small numbers. The presence of both confers a substantial additional risk, reaching $25 \%$ of observations having a $10 \%$ or greater cross-shift decrement of $\mathrm{FEV}_{1}$.

\section{Logistic Regression Models}

The results of logistic models of cross-shift decrement in $\mathrm{FEV}_{1}$ and $\mathrm{FVC}$, which use generalized estimating equations (GEE) to combine Monday and Thursday data across all three rounds of data collection, are presented in Table III. Based on the mean squared error, model fit for the FVC models is substantially better than for the $\mathrm{FEV}_{1}$ models. For both the FVC and $\mathrm{FEV}_{1}$ models, the fit of the thoracic bacteria model is marginally better than that of the thoracic particulate model. In all four models, those working on the second (afternoon) shift are substantially more likely than those on the first (day) shift to experience a $10 \%$ or greater cross-shift decrement. The coefficients and $p$ values for the main effects of Monday preshift obstruction and exposure measures must be interpreted with caution both because of the presence of the interaction terms and because the exposure measures are not on comparable scales, that is, mean thoracic particulate is about $0.3 \mathrm{mg} / \mathrm{m}^{3}$, whereas mean thoracic bacteria is about $9 \times 10^{5}$ bacteria $/ \mathrm{m}^{3}$.

Table IV presents comparative odds ratios based on the models in Table III to aid with interpretation of the models. In Table IV the model predictions for a nonobstructed subject with a relatively low exposure level is used as the base for comparing the risk of cross-shift decrements in pulmonary function in nonobstructed and obstructed sub-
TABLE III. GEE Logistic Regression Models ${ }^{a}$ for $10 \%$ or Greater Cross-Shift Decrement in Pulmonary Function ${ }^{b}$

\begin{tabular}{|c|c|c|c|c|}
\hline & \multicolumn{2}{|c|}{$\mathrm{FEV}_{1}$ models } & \multicolumn{2}{|c|}{ FVC models } \\
\hline & $\begin{array}{c}\text { Thoracic } \\
\text { particulate } \\
\text { model }\end{array}$ & $\begin{array}{c}\text { Thoracic } \\
\text { bacteria } \\
\text { model }\end{array}$ & $\begin{array}{c}\text { Thoracic } \\
\text { particulate } \\
\text { model }\end{array}$ & $\begin{array}{c}\text { Thoracic } \\
\text { bacteria } \\
\text { model }\end{array}$ \\
\hline Mean squared error & 0.0703 & 0.0694 & 0.0328 & 0.0311 \\
\hline Constant & $\begin{array}{r}-4.0138 \\
0.6564 \\
(<0.0001)\end{array}$ & $\begin{array}{c}-1.2070 \\
2.1220 \\
(0.57)\end{array}$ & $\begin{array}{r}-6.6271 \\
1.1891 \\
(<0.0001)\end{array}$ & $\begin{array}{l}0.0043 \\
2.9955 \\
(1.0)\end{array}$ \\
\hline Shift $(0=1 s t, 1=2$ nd $)$ & $\begin{array}{r}1.4410 \\
0.4687 \\
(0.002)\end{array}$ & $\begin{array}{r}1.5631 \\
0.4823 \\
(0.001)\end{array}$ & $\begin{array}{c}3.0786 \\
1.0814 \\
(0.004)\end{array}$ & $\begin{array}{r}3.1970 \\
1.0815 \\
(0.003)\end{array}$ \\
\hline $\begin{array}{c}\text { Obstructed ( } 1=\text { Monday } \\
\text { preshift } F E V_{1} / F V C \leq \\
0.72,0=\text { otherwise) }\end{array}$ & $\begin{array}{c}2.3698 \\
0.8125 \\
(0.004)\end{array}$ & $\begin{array}{c}-2.4532 \\
2.8785 \\
(0.40)\end{array}$ & $\begin{array}{r}3.6026 \\
1.0079 \\
(<0.0001)\end{array}$ & $\begin{array}{r}-6.4693 \\
3.6804 \\
(0.078)\end{array}$ \\
\hline Thoracic particulate levelc & $\begin{array}{c}-0.1077 \\
0.3235 \\
(0.74)\end{array}$ & & $\begin{array}{c}-0.3509 \\
0.4245 \\
(0.41)\end{array}$ & \\
\hline $\begin{array}{c}\text { Thoracic particulate level/ } \\
\text { obstructed interaction }\end{array}$ & $\begin{array}{l}0.6905 \\
0.5409 \\
(0.20)\end{array}$ & & $\begin{array}{l}1.7372 \\
0.6768 \\
(0.010)\end{array}$ & \\
\hline Bacteria leveld & & $\begin{array}{c}-0.2131 \\
0.1638 \\
(0.19)\end{array}$ & & $\begin{array}{r}-0.4985 \\
0.2303 \\
(0.031)\end{array}$ \\
\hline $\begin{array}{l}\text { Bacteria level/obstructed } \\
\text { interaction }\end{array}$ & & $\begin{array}{l}0.3191 \\
0.2226 \\
(0.15)\end{array}$ & & $\begin{array}{l}0.6604 \\
0.2890 \\
(0.022)\end{array}$ \\
\hline
\end{tabular}

aCombining Monday and Thursday for all three rounds of data collection.

bData in three-level stacks are:

Coefficient

Robust standard error

(Robust p-value)

cNatural logarithm of thoracic particulate in $\mathrm{mg} / \mathrm{m}^{3}$.

dNatural logarithm of thoracic bacteria in bacteria/ $\mathrm{m}^{3}$.

jects at higher exposure levels. The chosen levels for thoracic particulate $\left(0.14,0.34\right.$, and $\left.0.57 \mathrm{mg} / \mathrm{m}^{3}\right)$ are close to the mean exposures in Assembly, Valve Body, and Case, respectively; those for bacteria $(0.2,1.0$, and 3.0 bacteria/cc) are also well within the range of measured values in the study. With respect to thoracic particulate, for both $\mathrm{FEV}_{1}$ and FVC there is a trend of increasing risk of $10 \%$ or greater cross-shift decrements with increasing exposure among obstructed subjects but not among nonobstructed subjects. As compared with the risk for low-exposure nonobstructed subjects, the risk at higher exposures among obstructed subjects is substantial and is highly significant. With respect to thoracic bacteria there is a statistically significant and substantial increased risk of cross-shift decrements in pulmonary function among obstructed subjects at all exposure 
TABLE IV. Comparative Odds Ratios ${ }^{\mathrm{a}}$ (with $95 \%$ Confidence Intervals) for a 10\% or Greater Cross-Shift Decrement in Pulmonary Function ${ }^{b}$

Comparative odds ratios for $\mathrm{FEV}_{1} \quad$ Comparative odds levels for FVC

\begin{tabular}{|c|c|c|c|c|c|c|}
\hline \multicolumn{7}{|c|}{ Exposure levels for thoracic particulate $\left(\mathrm{mg} / \mathrm{m}^{3}\right)$} \\
\hline & 0.14 & 0.34 & 0.57 & 0.14 & 0.34 & 0.57 \\
\hline \multirow[t]{2}{*}{ All other subjects } & 1.0 & 0.91 & 0.86 & 1.0 & 0.73 & 0.61 \\
\hline & & $(0.58,1.41)$ & $(0.36,2.04)$ & & $(0.39,1.37)$ & $(0.19,1.98)$ \\
\hline \multirow[t]{4}{*}{ Obstructed subjectsc } & 2.75 & 4.60 & 6.22 & 1.19 & 4.09 & 8.43 \\
\hline & $(0.89,8.43)$ & $(1.83,11.65)$ & $(2.19,17.78)$ & $(0.23,6.09)$ & $(1.09,15.32)$ & $(2.06,34.39)$ \\
\hline & \multicolumn{6}{|c|}{ Exposure levels for thoracic bacteria (bacteria/cc) } \\
\hline & 0.2 & 1.0 & 3.0 & 0.2 & 1.0 & 3.0 \\
\hline \multirow[t]{2}{*}{ All other subjects } & 1.0 & 0.71 & 0.57 & 1.0 & 0.45 & 0.26 \\
\hline & & $(0.41,1.23)$ & $(0.23,1.42)$ & & $(0.22,0.92)$ & $(0.08,0.87)$ \\
\hline \multirow[t]{2}{*}{ Obstructed subjectsc } & 4.29 & 5.13 & 5.79 & 4.90 & 6.43 & 7.55 \\
\hline & $(1.33,13.95)$ & $(1.66,15.69)$ & $(1.77,19.50)$ & $(1.23,19.62)$ & $(1.49,27.08)$ & $(1.50,37.77)$ \\
\hline
\end{tabular}

aUsing nonobstructed subject with exposure level of $0.14 \mathrm{mg} / \mathrm{m}^{3}$ of thoracic particulate or 0.2 bacteria/cc of thoracic bacteria as the comparison base. ${ }^{b}$ Based on the following GEE models combining Monday and Thursday data across all three rounds: logit $\mathrm{P}(10 \%$ or greater cross-shift decrement in $\mathrm{FEV}_{1}$ [or $\left.\left.\mathrm{FVC}\right]\right)=\mathrm{B}_{0}+\mathrm{B}_{1}$ shift $+\mathrm{B}_{2}$ obstructed $+\mathrm{B}_{3}$ In of exposure measure $+\mathrm{B}_{4}$ obstructed* In of exposure measure.

CObstructed $=1$ if Monday preshift $F E V_{1} / F V C \leq 0.72 ;=0$ otherwise.

levels compared with that of nonobstructed subjects with low-level exposure. While the trend of increasing risk with increasing exposure among those with obstruction is not as strong for thoracic bacteria as for thoracic particulate, the specific values of the odds ratios are quite comparable between the two exposure measures. In the thoracic bacteria models, there is a trend of decreasing risk with increasing exposure among nonobstructed subjects.

\section{Linear Models}

The results of linear models of fractional cross-shift change in $\mathrm{FEV}_{1}$ and $\mathrm{FVC}$ that use generalized estimating equations (GEE) to combine Monday and Thursday across all three rounds are presented in Table V. As with the logistic models, model fit for FVC models was better than for FEV models; however, there was no difference in model fit between the respective thoracic particulate and thoracic bacteria models. Working on second shift was significantly associated with an additional decrement of $3-4 \%$ in $\mathrm{FEV}_{1}$ models and 2-3\% in FVC models. As with the logistic models, the coefficients and $p$ values for the main effects of Monday preshift $\mathrm{FEV}_{1} / \mathrm{FVC}$ and the exposure measures must be interpreted with caution owing to the presence of the interaction terms and the differences in exposure scales. Table VI presents predicted fractional changes in $\mathrm{FEV}_{1}$ and $\mathrm{FVC}$ for selected values of Monday preshift $\mathrm{FEV}_{1} / \mathrm{FVC}$ ratio and exposure levels based on the models in Table V. Across all four models, subjects with obstructive Monday preshift PFTs, that is, $\mathrm{FEV}_{1} / \mathrm{FVC}$ ratios of 0.7 or 0.6 , are predicted to have increasing decrements in pulmonary function with increasing exposure levels. In contrast subjects with nonobstructive baselines $\left(\mathrm{FEV}_{1} / \mathrm{FVC}=0.8\right)$ show little variation in predicted decrement with changing exposure in any of the four models. Across all four models, among subjects exposed to moderate to relatively high levels of thoracic particulate or thoracic bacteria, decreasing baseline $\mathrm{FEV}_{1} /$ FVC ratios are associated with increasingly large decrements in cross-shift FEV 1 and FVC. In contrast, among subjects with relatively low exposures (i.e., $0.14 \mathrm{mg} / \mathrm{m}^{3}$ of thoracic particulate or 0.2 thoracic bacteria/cc) the association of baseline $\mathrm{FEV}_{1} / \mathrm{FVC}$ with cross-shift decrements is absent or weak.

Table VII presents tabular results for Monday changes in $\mathrm{FEV}_{1}$ for those reporting current asthma plus those with a $12 \%$ or greater cross-shift change in Monday $\mathrm{FEV}_{1}$ in at least one round. The figure $12 \%$ was chosen on the basis of ATS recommendations for the diagnosis of occupational asthma [American Thoracic Society, 1993]. Nine of 83 subjects working in Machining areas demonstrated cross-shift decrements in $\mathrm{FEV}_{1}$ of $12 \%$ or greater in at least one round, as compared with 2 of 46 subjects working in Assembly demonstrating such decrements. Two of the 5 subjects working in Machining areas who reported current asthma experienced $12 \%$ or greater cross-shift decrements in $\mathrm{FEV}_{1}$, as compared with none of the three subjects working in Assembly reporting current asthma. Among the 9 subjects in Machining areas and 2 subjects in Assembly who demonstrated $12 \%$ or greater decrements in Monday $\mathrm{FEV}_{1}$, only one from each working environment reported asthma prior to working at this facility (a total of 2 of 11). 
TABLE V. GEE Linear Models ${ }^{a}$ for Fractional Cross-Shift Change ${ }^{b}$ in Pulmonary Function ${ }^{c}$

\begin{tabular}{|c|c|c|c|c|}
\hline & \multicolumn{2}{|c|}{$\mathrm{FEV}_{1}$ models } & \multicolumn{2}{|c|}{ FVC models } \\
\hline & $\begin{array}{c}\text { Thoracic } \\
\text { particulate } \\
\text { model }\end{array}$ & $\begin{array}{c}\text { Thoracic } \\
\text { bacteria } \\
\text { model }\end{array}$ & $\begin{array}{c}\text { Thoracic } \\
\text { particulate } \\
\text { model }\end{array}$ & $\begin{array}{c}\text { Thoracic } \\
\text { bacteria } \\
\text { model }\end{array}$ \\
\hline Mean squared error & 0.0029 & 0.0029 & 0.0019 & 0.0019 \\
\hline Constant & $\begin{array}{r}-0.0076 \\
0.0032 \\
(0.019)\end{array}$ & $\begin{array}{r}-0.0080 \\
0.0032 \\
(0.012)\end{array}$ & $\begin{array}{r}-0.0114 \\
0.0030 \\
(<0.0001)\end{array}$ & $\begin{array}{r}-0.0114 \\
0.0030 \\
(0.002)\end{array}$ \\
\hline $\begin{array}{l}\text { Shift }(0=1 s t, \\
\qquad 1=2 \mathrm{nd})\end{array}$ & $\begin{array}{r}-0.0359 \\
0.0066 \\
(<0.0001)\end{array}$ & $\begin{array}{r}-0.0391 \\
0.0068 \\
(<0.0001)\end{array}$ & $\begin{array}{r}-0.0229 \\
0.0053 \\
(<0.0001)\end{array}$ & $\begin{array}{r}-0.0250 \\
0.0053 \\
1<0.0001\end{array}$ \\
\hline $\begin{array}{l}\text { Monday preshift } \\
\mathrm{FEV}_{1} / \mathrm{FVC}\end{array}$ & $\begin{array}{l}0.0012 \\
0.0009 \\
(0.17)\end{array}$ & $\begin{array}{l}0.0012 \\
0.0009 \\
(0.16)\end{array}$ & $\begin{array}{r}0.0011 \\
0.0006 \\
(0.064)\end{array}$ & $\begin{array}{l}0.0011 \\
0.0006 \\
(0.064)\end{array}$ \\
\hline $\begin{array}{l}\text { Thoracic particulate } \\
\text { level }^{\text {d }}\end{array}$ & $\begin{array}{c}-0.0051 \\
0.0038 \\
(0.18)\end{array}$ & & $\begin{array}{c}-0.0042 \\
0.0036 \\
(0.24)\end{array}$ & \\
\hline $\begin{array}{l}\text { Thoracic particulate/ } \\
\text { Monday preshift } \\
\mathrm{FEV}_{1} / \mathrm{FVC} \text { interaction }\end{array}$ & $\begin{array}{l}0.0025 \\
0.0011 \\
(0.023)\end{array}$ & & $\begin{array}{l}0.0012 \\
0.0008 \\
(0.13)\end{array}$ & \\
\hline Thoracic bacteria levele & & $\begin{array}{c}-0.0012 \\
0.0018 \\
(0.51)\end{array}$ & & $\begin{array}{c}-0.0006 \\
0.0016 \\
(0.71)\end{array}$ \\
\hline $\begin{array}{l}\text { Bacteria level/Monday } \\
\text { preshift } \mathrm{FEV}_{1} / \mathrm{FVC} \\
\text { interaction }\end{array}$ & & $\begin{array}{l}0.0005 \\
0.0003 \\
(0.12)\end{array}$ & & $\begin{array}{r}0.0011 \\
0.0005 \\
(0.023)\end{array}$ \\
\hline
\end{tabular}

aCombining Monday and Thursday for all three rounds of data collection.

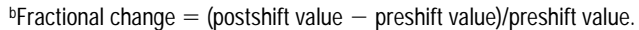

'Data in three-level stacks are:

Coefficient

Robust standard error

(Robust p-value)

dNatural logarithm of thoracic particulate in $\mathrm{mg} / \mathrm{m}^{3}$.

eNatural logarithm of thoracic bacteria in bacteria/ $\mathrm{m}^{3}$.

The results for Thursday cross-shift changes in $\mathrm{FEV}_{1}$ (and FVC) among current asthmatics and those with $12 \%$ or greater changes were quite similar to those for Monday (not shown). Of particular note, 6 of 83 (7.2\%) subjects working in Machining areas, but none of the 46 subjects working in Assembly, demonstrated cross-day decrements in at least one round (Monday or Thursday, $\mathrm{FEV}_{1}$ or FVC) of greater than $19 \%$, chosen as a magnitude that, it is believed, almost all medical practitioners would agree is of unequivocal clinical significance (Fisher's exact test, one-tailed: $p=.07$ ). Of those 6 subjects, 5 demonstrated such changes for Monday $\mathrm{FEV}_{1}$ (Subjects 1, 2, 9, 13, and 14 in Table VII). The sixth subject, Subject 10, experienced a $21.5 \%$ decrement in Round 1 Thursday $\mathrm{FEV}_{1}$ (data not shown). All but one of these six subjects had evidence of baseline obstruction (Monday preshift $\mathrm{FEV}_{1} / \mathrm{FVC}$ ration $\leq 0.72$ ) and were current smokers.

\section{Respiratory Symptoms}

Baseline respiratory symptoms and asthma history data from Round 1 are displayed in Table VIII. For every symptom, workers in Machining areas were more likely to report the symptom than those in Assembly, although only for phlegm $(\mathrm{OR}=3.1)$ and chronic bronchitis $(\mathrm{OR}=6.8)$ were these differences significant at an $\alpha=.05$ level. There were no significant differences in reported history of asthma.

\section{Development of Symptoms During the Shift}

The percentages of subjects within each department without each of a set of specific symptoms at the beginning of shift on Monday who developed that symptom during the shift on Monday in Round 1 are presented in Table IX. Those working in Machining departments were significantly more likely than those working in Assembly to develop at least one new lower respiratory symptom. The same pattern was observed for each specific lower respiratory symptom, although these differences did not reach statistical significance. A similar, though less significant pattern, was observed for new mucous membrane irritant symptoms, whereas no pattern was apparent for constitutional symptoms. On Thursday, machinists were only marginally more likely to develop new lower respiratory symptoms (not shown), and there were no significant differences in new mucous membrane irritant symptoms. Data from Rounds 2 and 3 for Monday and Thursday were quite similar (not shown). In these rounds, greater interdepartmental differences in the likelihood of new symptom development were found on Monday than on Thursday. In each case where differences for lower respiratory or mucous membrane irritant symptoms reached significance, the symptom was more common among workers in machining areas.

To investigate PFT-symptom relationships, the percentage changes (postshift - preshift) in Monday $\mathrm{FEV}_{1}$ from all three rounds were combined and then stratified into three levels: $<-10 \% ;-10 \%$ to $-5 \%$; $>-5 \%$. The percentages of workers developing at least one lower respiratory symptom during the corresponding Monday shift were, respectively, $46.6 \%, 25.0 \%, 15.3 \%$ for the three categories of percentage change in $\operatorname{FEV}_{1}(p<.001$, test for trend).

\section{DISCUSSION}

The only previous published epidemiologic study of acute respiratory effects among workers exposed to metal- 
TABLE VI. Predicted Cross-Shift Fractional Change ${ }^{a}$ in Pulmonary Function ${ }^{b}$ for a Subject Working on Second Shiftc

\begin{tabular}{|c|c|c|c|c|c|c|c|}
\hline \multirow{2}{*}{$\begin{array}{l}\text { Monday preshift } \\
\text { FEV }_{1} / \text { FVC ratio }\end{array}$} & \multicolumn{7}{|c|}{ Monday preshift } \\
\hline & \multicolumn{3}{|c|}{ Predicted change in $\mathrm{FEV}_{1}$} & $\mathrm{FEV}_{1} / \mathrm{FVC}$ ratio & \multicolumn{3}{|c|}{ Predicted change in FVC } \\
\hline \multicolumn{8}{|c|}{ Exposure level of thoracic particulate $\left(\mathrm{mg} / \mathrm{m}^{3}\right)$} \\
\hline & 0.14 & 0.38 & 0.57 & & 0.14 & 0.34 & 0.57 \\
\hline 0.8 & $-0.041(0.005)$ & $-0.040(0.005)$ & $-0.039(0.006)$ & 0.8 & $-0.031(0.003)$ & $-0.031(0.002)$ & $-0.032(0.003)$ \\
\hline 0.7 & $-0.037(0.008)$ & $-0.058(0.011)$ & $-0.070(0.015)$ & 0.7 & $-0.034(0.007)$ & $-0.045(0.007)$ & $-0.052(0.009)$ \\
\hline 0.6 & $-0.033(0.013)$ & $-0.076(0.022)$ & $-0.101(0.030)$ & 0.6 & $-0.037(0.011)$ & $-0.059(0.013)$ & $-0.072(0.019)$ \\
\hline \multicolumn{8}{|c|}{ Exposure level of thoracic bacteria (bacteria/cc) } \\
\hline & 0.2 & 1.0 & 3.0 & & 0.2 & 1.0 & 3.0 \\
\hline 0.8 & $-0.046(0.005)$ & $-0.043(0.004)$ & $-0.041(0.004)$ & 0.8 & $-0.034(0.004)$ & $-0.033(0.003)$ & $-0.032(0.003)$ \\
\hline 0.7 & $-0.047(0.009)$ & $-0.062(0.012)$ & $-0.072(0.015)$ & 0.7 & $-0.040(0.006)$ & $-0.047(0.008)$ & $-0.052(0.010)$ \\
\hline 0.6 & $-0.048(0.016)$ & $-0.081(0.022)$ & $-0.103(0.029)$ & 0.6 & $-0.046(0.010)$ & $-0.061(0.014)$ & $-0.071(0.019)$ \\
\hline
\end{tabular}

aFractional change $=($ postshift value - preshift value $) /$ preshift value.

bPrediction based on the following GEE models combining Monday and Thursday data across all three rounds: Fractional change in $\mathrm{FEV}_{1}[0 \mathrm{FVC}]=\mathrm{B}_{0}+\mathrm{B}_{1}$ shift $+\mathrm{B}_{2}$ Monday preshift FEV $/ F V C$ ratio $+\mathrm{B}_{3}$ In of exposure measure $+\mathrm{B}_{4}$ Monday preshift $\mathrm{FEV}_{1} / \mathrm{FVC}$ ratio* In of exposure measure.

'Data are predicted change (standard error of the mean).

working fluid aerosols was conducted by Kennedy et al. [1989]. Their study was similar in its design and number of subjects to our study; however, the subjects were studied for only one week. The Kennedy study measured cross-shift changes in lung function among 89 machine operators and 42 assemblers at two automotive plants. The participants had worked for a minimum of five years. The exposure measure of interest was thoracic (referred to as "inhalable" in the Kennedy article) particulate (particulate $\leq 9.8 \mu \mathrm{m}$ ). Workers wore air-sampling pumps on Monday and Friday of a single work week, and pre- and postshift spirometry were performed on both days. Median exposures to soluble oils in the Kennedy study, about $0.55 \mathrm{mg} / \mathrm{m}^{3}$ of thoracic particulate, are similar to exposures measured in the current study. In the Kennedy study machinists exposed to metalworking fluid were two-and-a-half times more likely to have a $5 \%$ or greater decrease in $\mathrm{FEV}_{1}$ (an ' $\mathrm{FEV}_{1}$ response') on Monday than nonexposed assembly workers (as compared to 1.6 times, $42.9 \%$ vs. $26.8 \%$, in the current study). After adjusting for race, childhood asthma, and smoking prior to spirometry, odds ratios (from logistic regression) for an $\mathrm{FEV}_{1}$ response were 4.4 for straight mineral oils, 5.8 for oil emulsions (i.e., soluble oils, as used in the current study), and 6.9 for synthetic fluids. $\mathrm{FEV}_{1}$ responses were similar on Fridays, but were not significant. There was also a significant linear dose-response trend between $\mathrm{FEV}_{1}$ response and exposure level on Friday but not on Monday. $\mathrm{FEV}_{1}$ did not progressively decline over a workweek. The current study also demonstrated positive associations of working in machining areas (Fig. 1) and higher exposures to thoracic particulate (Fig. 2) with decrements in PFTs (especially Monday $\mathrm{FEV}_{1}$ ) and also found no progressive decline over a workweek; that is, Monday and Thursday values were not significantly different. The authors of the Kennedy study concluded that acute airflow obstruction was associated with thoracic particulate exposures at least as low as $0.2 \mathrm{mg} / \mathrm{m}^{3}$.

Our study differed from Kennedy et al. in two important respects. First, the exposure assessment strategy for our study was more comprehensive. Briefly, we expected that thoracic particulate, which represents the fraction reaching the tracheobronchial tree and gas exchange regions of the lung, would be most significant. On the basis of prior studies in other settings, we hypothesized thoracic bacteria or associated products such as endotoxin as likely causative agents for acute respiratory effects. In a pilot phase of the study, fungi, metals, and gaseous microbial products $\left(\mathrm{NH}_{3}\right.$, $\mathrm{H}_{2} \mathrm{~S}$ ) were eliminated from consideration owing to low colony counts or concentrations. The presence of metalworking fluids in our study plant, together with the plant strategy of minimizing biocide use, resulted in substantial ambient bacterial counts.

Second, the findings in our study are not entirely comparable to the Kennedy study in that Kennedy et al. did not consider baseline obstruction as a covariate. In multivariable analyses, we found a strong interaction of preshift Monday $\mathrm{FEV}_{1} / \mathrm{FVC}$ ratio with exposure measures in predicting cross-shift decrements. Among obstructed subjects, but not among nonobstructed subjects, we found a consistent association between increasing thoracic particulate exposure and greater cross-shift decrements in both $\mathrm{FEV}_{1}$ and FVC in both logistic (Table IV) and linear (Table VI) models. Findings with thoracic bacteria used as the exposure measure were quite similar (Tables IV and VI). These results are consistent with assignment of responsibility for the observed effect to thoracic bacterial concentrations themselves or some other parameter correlated with bacterial concentra- 
TABLE VII. Subjects Reporting Current Asthma and/or a $12 \%$ or Greater Change in Monday FEV $\mathrm{V}_{1}$ in at Least One Round

\begin{tabular}{|c|c|c|c|c|c|c|c|c|c|c|c|c|c|c|c|c|}
\hline \multirow[b]{2}{*}{$\begin{array}{l}\text { Sub- } \\
\text { ject }\end{array}$} & \multirow[b]{2}{*}{$\begin{array}{l}\text { Reports } \\
\text { current } \\
\text { asthma }\end{array}$} & \multirow[b]{2}{*}{ Dept. } & \multirow{2}{*}{$\begin{array}{c}\text { Reports } \\
\text { asthma } \\
\text { in prior } \\
\text { work }\end{array}$} & \multirow[b]{2}{*}{$\begin{array}{c}\text { Smoking } \\
\text { status }\end{array}$} & \multicolumn{4}{|c|}{ Round 1} & \multicolumn{4}{|c|}{ Round 2} & \multicolumn{4}{|c|}{ Round 3} \\
\hline & & & & & $\mathbf{B R}^{\mathrm{a}}$ & $\begin{array}{c}\mathrm{TPb} \\
\mathrm{mg} / \mathrm{m}^{3}\end{array}$ & $\begin{array}{l}\text { Bacteria } \\
\text { per } \mathrm{cm}^{3}\end{array}$ & $\begin{array}{c}\text { Fractional } \\
\text { change } \\
\text { in } \mathrm{FEV}_{1}\end{array}$ & $\mathbf{B R}^{\mathrm{a}}$ & $\begin{array}{c}\mathrm{TPb} \\
\mathrm{mg} / \mathrm{m}^{3}\end{array}$ & $\begin{array}{l}\text { Bacteria } \\
\text { per } \mathrm{cm}^{3}\end{array}$ & $\begin{array}{c}\text { Fractional } \\
\text { change } \\
\text { in } \mathrm{FEV}_{1}\end{array}$ & $\mathbf{B R}^{\mathrm{a}}$ & $\begin{array}{c}\mathrm{TPb} \\
\mathrm{mg} / \mathrm{m}^{3}\end{array}$ & $\begin{array}{l}\text { Bacteria } \\
\text { per } \mathrm{cm}^{3}\end{array}$ & $\begin{array}{c}\text { Fractional } \\
\text { change } \\
\text { in } \mathrm{FEV}_{1}\end{array}$ \\
\hline 1 & Yes & Case & Yes & Yes & 43 & 0.46 & 2.88 & -0.253 & $36^{c}$ & 0.56 & 0.49 & $0.156^{c}$ & $41^{c}$ & 1.36 & 39.56 & $-0.106^{c, d}$ \\
\hline 2 & Yes & Case & No & Yes & 59 & 0.51 & 0.74 & -0.193 & 65 & 0.82 & 5.23 & -0.189 & - & - & - & - \\
\hline 3 & Yes & Case & No & Yes & 79 & 0.42 & 2.63 & 0.004 & - & - & & - & - & - & - & - \\
\hline 4 & Yes & Case & Yes & No & 84 & 0.56 & 1.50 & 0.073 & 84 & 0.70 & 3.40 & -0.031 & 83 & 0.36 & 4.25 & -0.050 \\
\hline 5 & Yes & Case & No & Yes & 82 & 0.34 & 1.47 & -0.005 & - & - & - & - & - & - & - & - \\
\hline 6 & Yes & Assy & Yes & Yes & 69 & 0.20 & 0.19 & 0.202 & - & - & - & - & - & - & - & - \\
\hline 7 & Yes & Assy & No & Yes & 83 & 0.17 & 0.49 & 0.052 & 81 & 0.15 & 0.014 & 0.104 & 83 & 0.09 & 1.35 & -0.071 \\
\hline 8 & Yes & Assy & Yes & No & - & 0.14 & 0.14 & -0.003 & 52 & 0.16 & 0.16 & $0.355^{\mathrm{e}}$ & 59 & 0.07 & 0.41 & 0.113 \\
\hline 9 & No & Case & No & Yes & 48 & 0.61 & 2.58 & -0.408 & 42 & 0.74 & 1.40 & -0.317 & 43 & 0.54 & 10.47 & -0.394 \\
\hline 10 & No & Case & No & Yes & 72 & 0.56 & 1.36 & -0.136 & 69 & 0.66 & 3.19 & -0.184 & - & - & - & - \\
\hline 11 & No & Case & No & No & 89 & 0.38 & 0.18 & -0.124 & - & - & - & - & 84 & 0.36 & 3.08 & -0.113 \\
\hline 12 & No & Case & No & Yes & 81 & 0.77 & 1.93 & -0.041 & 86 & 0.80 & 0.96 & -0.168 & 78 & 0.56 & 17.19 & -0.069 \\
\hline 13 & No & Valve & No & Yes & 72 & 0.31 & 3.43 & -0.113 & 79 & 0.17 & 0.007 & -0.248 & 77 & 0.17 & 0.31 & -0.120 \\
\hline 14 & No & Valve & No & No & 81 & 0.23 & 0.26 & -0.196 & - & - & - & - & - & - & - & - \\
\hline 15 & No & Valve & No & Ex & 79 & 0.26 & 0.22 & -0.008 & 69 & 0.26 & 0.030 & 0.127 & - & - & - & - \\
\hline 16 & No & Valve & No & No & 87 & 0.18 & 0.44 & -0.130 & - & - & - & - & - & - & - & - \\
\hline 17 & No & Assy & No & No & - & - & - & - & - & 0.11 & 0.37 & -0.161 & - & - & - & - \\
\hline 18 & No & Assy & No & No & - & - & - & - & 82 & 0.15 & 0.16 & -0.180 & - & - & - & - \\
\hline
\end{tabular}

aBaseline ratio $=100\left(\mathrm{FEV}_{1} / \mathrm{FVC}\right)$ preshift Monday.

bThoracic particulate.

cSmoking status changed to exsmoker.

"Used inhaler during shift.

eUsed "sinus medication" during shift.

tions (e.g., the correlation coefficient with endotoxin measures was 0.9 ). In this context it is notable that endotoxin exposure has been associated with acute decrements in pulmonary function [Castellan et al., 1987]. However, these findings are equally consistent with the conclusion that other constituents of the metalworking fluid aerosols, which may also be correlated with bacterial concentrations, are responsible. The correlation between thoracic particulate and thoracic bacteria levels varied from $r=0.55$ to 0.70 across rounds. If bacteria are playing a role, the available data do not allow one to say whether the observed effects are associated primarily with any particular bacterial family or species (beyond the overwhelming predominance of Gramnegative rods), in that less than half of the bacterial colonies grown could be identified with available biotest kits [Burge et al., 1995]. Similarly, one cannot determine from these data whether the association is with total bacteria (viable plus nonviable), measured by the acridine orange direct count method used, or with culturable bacteria only, which is the method most commonly used to assess bacterial levels in metalworking fluids.
The central finding of consistent associations between lower baseline $\mathrm{FEV}_{1} / \mathrm{FVC}$ ratio and larger cross-shift decrements in $\mathrm{FEV}_{1}$ and $\mathrm{FVC}$ is particularly intriguing because the direction of causality (if any) cannot be determined from this study with data collection restricted to a relatively short, 1 -year period. The same week temporal direction is clear; that is, baseline ratio is measured prior to occurrence of any cross-day or cross-week decrements. However, it is biologically plausible and consistent with the available data that the primary reason for the observed association is that pulmonary effects associated with the experience of repeated cross-day or cross-week decrements over a period of years causally leads to more permanent, irreversible adverse pulmonary changes that are reflected in the observed lower baseline ratios, as has been suggested or reported in a number of studies of other agents [Peters, 1974; Weill, 1984; Becklake et al., 1988; Hankinson and Hodous, 1983; Christiani et al., 1994; Glindmeyer et al., 1994; Becklake, 1995]. An alternative explanation is that individuals with inherently lower pulmonary function, or who have been more susceptible to the effects of other pulmonary irritants 
TABLE VIII. Percentage of Subjects Within Each Department Reporting Baseline Symptoms (Round 1)

\begin{tabular}{|c|c|c|c|c|c|}
\hline Symptom ${ }^{a}$ & $\begin{array}{c}\text { Assembly } \\
\mathrm{n}=\mathbf{3 4}\end{array}$ & $\begin{array}{c}\text { Case } \\
\mathbf{n}=\mathbf{5 2 ^ { b }}\end{array}$ & $\begin{array}{c}\text { Valve } \\
\mathrm{n}=\mathbf{3 0}\end{array}$ & $\begin{array}{c}\text { p value } \\
\text { comparing } \\
\text { departments }\end{array}$ & $\begin{array}{c}\text { p value }^{c} \\
\text { assemblers vs. } \\
\text { machinists }\end{array}$ \\
\hline Cough & 35 & 46 & 50 & .453 & .247 \\
\hline Chronic cough & 15 & 31 & 17 & .148 & .211 \\
\hline Phlegm & 26 & 48 & 60 & .022 & .012 \\
\hline Chronic phlegm & 15 & 25 & 27 & .433 & .211 \\
\hline Chronic bronchitis & 3 & 19 & 13 & .088 & .041 \\
\hline Wheezing & 38 & 50 & 50 & .512 & .271 \\
\hline Wheezing w/dyspnea & 12 & 21 & 23 & .431 & .212 \\
\hline Grade 1 dyspnea & 24 & 29 & 47 & .121 & .213 \\
\hline Grade 2 dyspnea & 3 & 12 & 7 & .320 & .212 \\
\hline Ever had asthma & 12 & 13 & 0 & .116 & .575 \\
\hline Had asthma in prior work & 9 & 8 & 0 & .266 & .407 \\
\hline
\end{tabular}

aSee Methods section for definitions of symptoms.

bFor Case in Round 1, $\mathrm{n}=51$ for Grade 1 Dyspnea and Grade 2 Dyspnea.

"For test of equal proportions, where "comparing departments" means comparing Assembly, Case, and Valve, and "assemblers vs. machinists" means comparing assemblers to machinists after combining Case and Valve.

such as cigarette smoke, are more sensitive to irritating or bronchoconstrictive effects of metalworking fluids aerosols.

The potential contributory role of cigarette smoking to the adverse acute respiratory effects of metalworking fluid aerosols is intriguing. In preliminary analyses (not shown), being a current smoker, and greater number of pack-years smoked, were frequently associated with greater cross-shift decrements among subjects exposed to machining fluid aerosols. However, when these were compared with analyses using baseline obstruction in place of smoking parameters, the models using obstruction showed substantially more consistent and significant associations and better model fit, suggesting that the observed effects were associated with the physiologic presence of baseline obstruction independent of cause. Models incorporating both obstruction and smoking parameters were difficult to interpret owing to multicollinearity, although they did suggest that an independent effect of obstruction on the association between exposure levels and cross-shift decrements in pulmonary function was present even with control for cigarette smoking. To avoid problems of multicollinearity, age was not included in these models. However, it appears unlikely that this is an age-related effect, because additional models using age rather than pack-years or baseline obstruction showed generally less significant associations and a poorer model fit and the age range of the study population was quite narrow, and because there was no reason a priori to expect age to be associated with cross-shift changes in pulmonary functions.

The reasons for the lower mean $\mathrm{FEV}_{1}$ and FVC percentage predicted in Round 2 as compared with Rounds 1 and 3 are uncertain. Differences appear unlikely to be explained by systematic measurement error, as the calibration and administration methods, spirometers, and personnel were the same for all three rounds, although it should be noted that substantial interround differences under similar conditions have been reported in other longitudinal studies [Burrows et al., 1986]. One possible explanation is seasonal differences in plant ventilation, as Round 2 was conducted in the winter months, whereas the other two rounds were conducted in late spring and early summer.

The consistent associations of working on second shift with greater cross-shift decrements in $\mathrm{FEV}_{1}$ and FVC (3-4\% for $\mathrm{FEV}_{1}, 2-3 \%$ for FVC; see Table V) was to be expected on the basis of the diurnal variations in pulmonary function observed in many prior studies [Quackenboss et al., 1991; Troyanov et al., 1994; Hruby and Butler, 1975] (the median for hours awake prior to preshift pulmonary function testing was 1-2 hours for subjects on first shift and 5-6 hours for those on second shift).

Because of the concern that subjects reporting current asthma $(n=8)$ might demonstrate a different effect of exposure to metalworking fluids, additional regression models with these subjects excluded were examined. In all cases coefficients and associated $p$ values in these models were quite similar to the corresponding models including all subjects.

A closer examination of those subjects reporting current asthma and/or demonstrating the greatest cross-shift decrements in pulmonary function appears warranted because (a) they constitute those subjects who may be demonstrating pulmonary effects of clear clinical significance; and (b) they may indicate whether particular subpopulations of workers 
TABLE IX. Percentage of Subjects Within Each Department Without Selected Symptoms on Monday at the Beginning of the Shifta Who Developed the Symptom During Their Shift on Monday (Round 1)

\begin{tabular}{|c|c|c|c|c|c|}
\hline Symptom & Assembly & Case & Valve & $\begin{array}{c}\text { p value }{ }^{b} \\
\text { comparing } \\
\text { departments }\end{array}$ & $\begin{array}{c}\text { p value }^{c} \\
\text { assemblers vs. } \\
\text { machinists }\end{array}$ \\
\hline \multicolumn{6}{|l|}{ Respiratory symptoms } \\
\hline Dry cough & $4 \%$ & $10 \%$ & $22 \%$ & .086 & .124 \\
\hline Cough with phlegm & 11 & 23 & 22 & .409 & .194 \\
\hline Wheezing in chest & 0 & 4 & 4 & .514 & .259 \\
\hline Chest tightness & 0 & 9 & 10 & .176 & .067 \\
\hline Dyspnea & 0 & 7 & 8 & .266 & .110 \\
\hline Any new lower respiratory symptom & 12 & 35 & 37 & .037 & .012 \\
\hline \multicolumn{6}{|l|}{ Mucous membrane irritant symptoms } \\
\hline Irritation in nose & 0 & 0 & 0 & - & - \\
\hline Throat irritation & 6 & 11 & 12 & .752 & .464 \\
\hline Sinus trouble & 4 & 3 & 8 & .610 & .843 \\
\hline Eye irritation & 0 & 9 & 0 & .070 & .176 \\
\hline Any new mucous membrane irritant symptom & 6 & 19 & 17 & .217 & .089 \\
\hline \multicolumn{6}{|l|}{ Constitutional symptoms } \\
\hline Fever & 0 & 0 & 0 & - & - \\
\hline Headache & 6 & 6 & 3 & .850 & .773 \\
\hline Dizziness & 0 & 0 & 0 & - & - \\
\hline Fatigue (tiredness) & 0 & 4 & 12 & .130 & .142 \\
\hline J oint pains & 3 & 3 & 9 & .489 & .785 \\
\hline Any new constitutional symptom & 9 & 8 & 13 & .709 & .876 \\
\hline Skin irritation or rash & 0 & 0 & 0 & - & - \\
\hline
\end{tabular}

aNumber of subjects without symptoms at the beginning of the shift varied from 25 to 34 (out of 34) for Assembly, 35 to 52 (out of 52) for Case, and 23 to 30 (out of 30) for Valve Body for different symptoms.

${ }^{b}$ For test of equal proportions, comparing Assembly, Case, and Valve Body.

cFor test of equal proportions, after combining Case and Valve Body, in order to compare assemblers with machinists.

appear to be at particular risk for adverse effects. The findings that 6 of 83 subjects working in machining areas, but none of 46 subjects working in assembly, had greater than $19 \%$ cross-shift decrements in $\mathrm{FEV}_{1}$ or FVC, strongly suggests that exposures in machining areas using soluble oils are associated with clinically significant adverse acute pulmonary effects in some individuals (Table VII). The associations between exposures in machining areas and the development of lower respiratory and mucous membrane symptoms during the shift (Table IX) lends further support to the hypothesis that these exposures are related to clinically relevant adverse respiratory effects.

Our data suggest that one cannot predict with certainty which individuals may show unequivocal clinically significant adverse pulmonary effects (i.e., cross-shift decrements in $\mathrm{FEV}_{1}$ and $\mathrm{FVC}$ of greater than 19\%). Among those in machining areas the degree of pulmonary obstruction present at baseline (preshift Monday) was associated with marked decrements during the workshift. However, a baseline $\mathrm{FEV}_{\mathrm{l}} / \mathrm{FVC}$ ratio in the normal range did not guarantee a lack of clinically significant decrements (e.g., Subject 14 in Table VII had a baseline $\mathrm{FEV}_{1} / \mathrm{FVC}$ ratio of $81 \%$ but experienced a $20 \%$ decrement in Monday $\mathrm{FEV}_{1}$ ). Similarly, neither a relatively low thoracic particulate exposure nor a relatively low bacterial exposure ensured the lack of adverse acute effects. The apparent lack of threshold for acute respiratory effects is further supported by a series of analyses in which threshold models of cross-shift decrements in $\mathrm{FEV}_{1}$ and FVC were compared with linear no-threshold models. The no-threshold models consistently provided a better fit with the study data than models considering any of a range of candidate threshold values (not shown). Finally, at least in the "survivor" population studied, the presence of reported asthma prior to working at this facility was not a predictor of cross-shift pulmonary decrements. Only 1 of the 9 subjects working in machining who experienced Monday $\mathrm{FEV}_{1}$ decrements of $12 \%$ or greater reported such a prior history.

In considering the overall findings, certain limitations must be borne in mind. First, there is at least some potential 
for selection bias, as there are some differences between participants and eligible nonparticipants in Round 1 and between participants in Round 1 and those in subsequent rounds. However, it appears unlikely that systematic selection differences occurred. Most of the differences seen were in age, race, and shift. Age and race generally were not associated with outcomes of interest, and in all regression models, shift was adjusted for. Second, the study was conducted on a "survivor" population. The mean seniority among machinists was 19 years. If, in fact, exposure to metalworking fluids aerosols is associated with symptomatic respiratory effects, a study of this cohort is likely to underestimate such effects.

In summary, this study offers substantial evidence that metalworking fluid aerosol levels found in present-day U.S. machining operations are associated with clinically significant acute decrements in pulmonary function in some individuals. This conclusion is supported in that the pattern of cross-shift decrements observed is in reasonable agreement with the one prior comparable study [Kennedy et al., 1989].

In view of the lack of evidence for a threshold level for acute pulmonary decrements of $19 \%$ or greater, and the uncertainty regarding whether repeated smaller cross-day decrements may lead to chronic, irreversible pulmonary effects, it appears prudent that exposure levels in machining areas should be reduced to the lowest levels feasible. Our data suggest it is impractical to consider an exposure limit below $0.2 \mathrm{mg} / \mathrm{m}^{3}$ of thoracic particulate (equivalent to about $0.28 \mathrm{mg} / \mathrm{m}^{3}$ of total particulate; [Kennedy et al., 1989]), in that, among subjects working in Assembly, in which there were no discernible point sources for particulate exposure, the median thoracic particulate exposure was $0.14 \mathrm{mg} / \mathrm{m}^{3}$, the 75 th percentile was $0.15 \mathrm{mg} / \mathrm{m}^{3}$, and the maximum was $0.31 \mathrm{mg} / \mathrm{m}^{3}$.

Our data are equally consistent with attributing to bacteria or bacteria-related exposures, or to exposures to other unidentified components of machining fluids, the responsibility for the observed exposure-related cross-shift decrements in pulmonary function. Because current methods for airborne bacteria measurement are too labor-intensive and expensive for routine use, monitoring of thoracic or total particulate is recommended. It may be reasonable to institute additional measures (such as microfiltration and UV lights) to suppress bacterial growth and remove organisms. It is uncertain whether the routine use of biocides to suppress bacterial growth is warranted. Biocides may have adverse respiratory or other health effects, may cause undesirable changes in the predominant flora, and may not decrease endotoxin levels.

Given the prevalence of substantial cross-shift decrements in $\mathrm{FEV}_{1}$ and FVC in our study population, and the uncertainty of the long-term implications of these findings, it also appears prudent to institute a program of medical surveillance for workers potentially exposed to metalworking fluids aerosols. Under the supervision of an appropriately trained physician, a program that includes both baseline and periodic assessment of respiratory symptoms and pulmonary function (i.e., simple spirometry) is recommended. Finally, in view of the association of cross-shift decrements in $\mathrm{FEV}_{1}$ and $\mathrm{FVC}$ with baseline obstruction and the correlation of current smoking with baseline obstruction, inclusion of a program to encourage smoking cessation my prove beneficial.

\section{ACKNOWLEDGMENTS}

We would like to express our appreciation to the following people who spent countless hours assisting with data collection, laboratory analyses, and typing and editing of draft manuscripts: Renita Bellmore, Michael Patellos, Carrie Dahlstrom, Adrian Rocskay, Carolyn Doyle, Alfreda Rooks, Milton Dupuy, Victor Roth, Julie Garrett, Miriam Rozian, Daryl Johnson, Lorne Sanford, Elizabeth Johnston, Cathy Simpson, Jackie Kurtz, Jenny Su, Vikki Lewis, Rob Sulewski, Michael Muilenberg, Thersa Sweet, Nancy Nelson, Stephen Torrey, Polly Pan, and Wendy Ulin.

We would also like to thank the workers and management personnel at GM Powertrain in Warren, Michigan, for making this study possible.

We express our special appreciation to the two anonymous journal referees whose editorial assistance substantially improved this manuscript.

This project was funded wholly by joint funds from the United Automobile Workers/General Motors National Joint Committee on Health and Safety.

\section{REFERENCES}

Abrams L, Seixas N, Robins T, Burge H, Muilenberg M, Franzblau A: Characterization of metalworking fluids exposure indices for a study of acute respiratory effects. Submitted to AIHAJ.

American Thoracic Society (1978): Epidemiology Standardization Project: Recommended respiratory disease questionnaires for use with adults and children in epidemiological research. Am Rev Resp Dis 118(6):7-53.

American Thoracic Society (1987): Standardization of spirometry: update statement of the American Thoracic Society. Am Rev Respir Dis 136(5): 1285-1298.

American Thoracic Society (1993): Guidelines for the evaluation of impairment disability in patients with asthma. Am Rev Respir Dis 147:1056-1061.

Becklake MR (1995). Relationship of acute obstructive airway change to chronic (fixed) obstruction. Thorax 50(Suppl 1):516-521).

Becklake MR, Bourbean J, Menzies R, Ernst P (1988). The relationship between acute and chronic airway responses to occupational exposures. Curr Pulmonol 9:25-66. The Industrial Metalworking EnvironmentAssessment and Control: 234-240.

Burge H, Mulienbert M, Robins T (1995). Microbiology of metalworking fluids: pilot studies for a large scale exposure assessment experience. The Industrial Metalworking Environment-Assessment and Control: 234-240. 
Burrows B, Lebowitz MD, Camilli AE, Knudson RJ (1986): Longitudinal changes in forced expiratory volume in one second in adults. Am Rev Respir Dis 133:974-980.

Castellan RM, Olenchock SA, Kinsley KB, Hankinson JL (1987): Inhaled endotoxin and decreased spirometric values. An exposure-response relation for cotton dust. N Engl J Med 317(10):605-610.

Christiani DC, Ye TT, Wegman DH, Eisen EA, Dai HL, Lu PL (1994): Cotton dust exposure, across-shift drop in $\mathrm{FEV}_{1}$, and five-year change in lung function. Am J Respir Crit Care Med 150:1250-1255.

Dockery DW, Ware JH, Ferris BG, Glicksber DS, Fa ME, Spir A, Speizer FE (1985): Distribution of forced expiratory volume in one second and forced capacity in healthy, white, adult never-smokers in six U.S. cities. Am Rev Resp Dis 131:511-520.

Glindmeyer HW (1994): Cotton dust and across shift change in $\mathrm{FEV}_{1}$ as predictors of annual change in $\mathrm{FEV}_{1}$. Am J Respir Crit Care Med 149:584-90.

Hammond SK, Leaderer BP, Roche A, Schenker M (1987): Collection and analyses of nicotine as a marker for environmental tobacco smoke. Atmospheric Environ 21:457-462.

Hankinson JL, Hodous TK: (1983) 'Short-Term Prospective Spirometric Study of New Coal Miners.' NTTS PB83-237-446. Morgantown, WV: Clinical Investigations Branch, NIOSH.

Hendy MS, Beattie BE, Burge PS (1985): Occupational asthma due to an emulsified oil mist. Br J Indust Med 42:51-54.

Hobbie JE, Daley RJ, Jasper S (1977): Use of Nuclepore filters for counting bacteria by fluorescence microscopy. Appl Environ Microbiol 33:12251228.

Hruby J, Butler J (1975): Variability of routine pulmonary function tests. Thorax 30(5):548-553.

Kennedy SM, Greaves IA, Kriebel D, Eisen EA, Smith TJ, Woskie SR (1989). Acute pulmonary responses among automobile workers exposed to aerosols of metalworking fluids. Am J Ind Med 15:627-641.
Leaderer BP, Hammond SK (1991): Evaluation of vapor-phase nicotine and respirable suspended particle mass as markers for environmental tobacco smoke. Environ Sci Technol 25:770-777.

Liang K-Y, Zeger SL (1986): Longitudinal data analyses using generalized linear models. Biometrics 73:13-22.

Marple, V (1989): 'PEM Development, Fabrication, Evaluation and Calibration. ' Final Report to MSP Corporation. Subcontract No. 3-321U3933.

Milton DK, Gere RJ, Feldman HA, Greaves IA (1990): Endotoxin measurement aerosol sampling and application of a new limulus method. Am Ind Hyg Assoc J 51:331-337.

NIOSH (National Institute for Occupational Safety and Health) (1977): 'National Occupational Hazard Survey.' Publ 78-114. Washington, DC: USDHEW, p. 369.

Peters J (1974): The relationship of acute pulmonary effects on organic materials to chronic pulmonary effects. Ann NY Acad Med. 221:44-49

Quackenboss J, Lebowitz M, Krzyzanowksi M (1991): The normal range of diurnal changes in peak expiratory flow rates. Relationship to symptoms and respiratory disease. Am Rev Respir Dis 143:323-330.

Robertson AS, Weir DC, Burge PS (1988): Occupational asthma due to oil mists. Thorax 43:200-205.

Schaper M, Detwiler K (1991): Evaluation of the acute respiratory effects of aerosolized metalworking fluids in mice. Fundam Appl Toxicol 16(2):309319.

Troyanov S, Ghezzo H, Cartier A, Malo J (1994): Comparison of circadian variations using $\mathrm{FEV}_{1}$ and peak expiratory flow rates among normal and asthmatic subjects. Thorax 49(8):775-780.

Weill H (1984): Relations between acute and chronic occupational airway responses. In: Gee JBL, Morgan WKC, Brooks SM. (eds): 'Occupational Lung Disease.' New York: Raven Press, pp. 87-95.

Zeger SL, Liang K-Y (1986): Longitudinal data analyses for discrete and continuous outcomes. Biometrics 42:121-130. 